\title{
The Shi'ites, the West and the future of democracy: reframing political change in a religio-secular world
}

\author{
John A. Rees, University of New South Wales \\ What we ultimately owe Iraq is to let the Iraqis grasp nationhood and sovereignty for \\ themselves — and keep it, if they can. \\ Noah Feldman \\ In the vacuum left by the toppling of Saddam, the mosque was one of the few remaining threads of \\ the social fabric that survived. \\ Paul McGeough
}

\section{Introduction}

In the aftermath of the attacks upon Washington and New York in September 2001 (9/11), one of the central challenges posed to policy development is how secular and religious actors might together conceive a cohesive polity, or more poignantly, how the secular assumption of analysts and commentators might be challenged and corrected by the inclusion of religious actors and perspectives (Philpott 2002, Thomas 2005). In a context like occupied Iraq, itself a direct consequence of 9/11, where religious traditions constitute a primary structure of cultural and political power, the need to find some sort of secular-religious balance becomes acute. It is within the context of this debate that the award-winning Australian journalist Paul McGeough published an important analysis titled Mission Impossible: The Sheikhs, the US and the Future of Iraq (2004a). The present article critically reviews McGeough’s essay within the broader discussion of secular-religious relations in international affairs. 
The thesis of Mission Impossible can be summarised around two ideas: that the US strategy in Iraq was flawed because it wilfully bypassed the traditional power structures of Iraqi society; and that these structures, formed around the tribe and the mosque, are anti-democratic, thus rendering attempts at democratisation in Iraq impossible. This article affirms McGeough's argument concerning the gross inadequacy of the US strategy, but critically examines the author's fatalism toward the democratic capacity of Iraqi structures, notably the structure of the mosque. Focusing on the Shi'ite community as central actors in an emerging Iraqi democracy, the article attempts to deconstruct the author's secularist view that the world of the mosque exists in a 'parallel universe' to the liberal democratic West. By reframing the Shi'ites as essential actors in the democratic project, it situates political discourse in a 'religio-secular world' (Marty, 2003) thus bringing the 'other' worlds of religion and secularism together in a sphere of interdependence. Such an approach takes us beyond McGeough's orientalist posture toward the most prominent religious actors of Iraq, and emphasizes the importance of post-secular structures in the discourses on democratic change.

\section{Mission Impossible by Paul McGeough}

From the opening sentence, Mission Impossible reflects the kind of as-it-happened intensity expected from one of the most highly regarded journalists in Iraq. Reporting from deep context and reliant on 'Iraqi voices’ (2004a, iv), McGeough attempts to go beyond 'narrow and partisan examinations' (2004a, 8) of the occupation to analyse the conflict within the cultural traditions of the Middle East. In so doing, he sets out to describe a world that is radically unfamiliar to the Western cosmopolitan readerwelcome to an 'ethno-religious cauldron' (2004a, 34), to the domain of the sheikhs.

The world of the sheikhs

Mission Impossible bores into the 'bedrock’ (2004a, 8) of Iraqi culture, a conglomerate of tribal and Islamic traditions compacted together by ancient interests. The central actors between the tribe and the mosque are the sheikhs - 'men of power' (2004a, iii), the true rulers of Iraq and of the region. For McGeough the sheikhs have effectively suffocated US neo-conservative hopes for a democratic Iraq in much the same way they unravelled 
British plans for the region in the 1920s (2004a, 12). Significant for the present study, the domain of the sheikhs is described as 'another world, a parallel universe' (2004a, 4) to that of the West, held together by 'tradition, religion and rites' (2004a, 21) but not of democracy. On this latter point, McGeough is emphatic:

The more I saw of the sheikhs, and the more I talked with them, the more clearly I realised that the most fundamental power structures in Iraqi society run counter to those which underpin democracy (2004a, iii).

Understanding the world of the sheikhs thus requires 'using your mind's eye to erase the existing national boundaries' and a return to when 'what we now call the Middle East was carved up into warring tribal fiefdoms’ (2004a, 10). Tossing the American occupation into this 'swirling mix of tribal and mosque power' was unlikely to produce 'anything that Washington had in mind when it embarked on its project of regime change' (2004a, 42). The title, Mission Impossible, is therefore chiselled as an epitaph on the tomb of the US-led campaign that has become bogged in Babylon.

\section{'A pincers of its own making'}

From a strategic perspective, McGeough portrays the US mission in Iraq as a 'story of hubris' (2004a, iv) gone wrong. This is in large part because 'the neoconservative ideology of Dick Cheney, Donald Rumsfeld and Paul Wolfowitz took no account of the people and the culture of Iraq' (2004a, 7) who instead 'believed they could build their democracy mall without planning approval' (2004a, 7). More significantly, as with other moments of imperial over-stretch throughout history, in Iraq the coercive powers of the would-be conquerors seem no match for the cultural and historic arsenal of their wouldbe subjects. It is not the barbarian hordes, nor the Russian winter, nor the Hindu Kush that proves insurmountable this time, but forces that McGeough attributes with a quasimetaphysical quality: 'As the US focuses on its self-appointed task, around it, unseen, are the pillars of an ancient tribal society that, along with religious crossbeams of equal strength and proportions, are likely to doom the American quest.' (McGeough, 2004a, 4)

Indeed, the depth of mystery that animates the politics of tribe and mosque as reported by McGeough will challenge the most ardent positivist with the grim truth that 'kids from 
Texas and Idaho' (2004a) beamed into ancient cities like Fallujah and holy cities like Najaf have next to no chance of winning the Iraqis to their imperial cause. As one 'youthful lieutenant' exasperated, 'What does a sheikh look like? I go to meetings with people who dress and look like sheikhs, but they don't carry a sheikh ID card.' (2004a, 65) As if to then divulge the futility of his mission, Lieutenant Colonel Chris Hickey reasoned that until he can 'figure [the sheikhs] out' he will have to 'stand above tribal politics and deal with the higher goals of safety, peace and prosperity' (2004a, 65).

By stark contrast, McGeough believes there is no higher goal than figuring the sheikhs out. The failure to do so, in both the planning and the execution of the occupation, explains why 'the US is caught in a pincers of its own making, between the tribes and the mosque’ (2004a, 7) and reveals 'why today's Iraq is not the nursery for democracy that Washington wants it to be’ (2004, iv).

\section{Toward a critical appraisal of Mission Impossible}

There is no doubt Mission Impossible is replete with incisive commentary, whether by McGeough as narrator or by Iraqi and other voices that speak into the narrative. As a grass-roots record of perspectives emanating from the many publics of occupied Iraq, it is an invaluable resource. However, fundamental questions also exist concerning the central logic of the essay. For instance, if the traditional structures of tribe and mosque cannot be utilised in building a democratic Iraq, what are the alternatives? What assumptions undergird McGeough’s view that these structures have an anti-democratic ontology?

\section{The problematic logic of fatalism}

One of the defining textures of Mission Impossible, explicit in the title, is a fatalism about the future of Iraq. Yet what holds this fatalism together are what seem to be irreconcilable tensions: on the one hand, it was 'a very bad idea' (McGeough 2004a, 8) for the US to exclude the sheikhs in building a new democratic Iraq; on the other hand, the political structures of the sheikhs run 'counter to those which underpin democracy' (McGeough 2004, iii); on the one hand, McGeough trusts the judgement of Arab friends to lead him to study the sheikhs (2004a, iii); on the other hand, he does not trust the judgement of the 
tribes and the mosque with Iraq's future democratic affairs. Perhaps caught in a pincers of his own making, McGeough can only conclude that Iraq has become a 'feuding, vengeful mess' (2004a, 79) in a context where 'there is no room for tolerance or trust'; and that the most powerful discourse in the country exists not between the Iraqis and the Americans, but between the Iraqis themselves 'as they set the scene for a post-30 June carve-up of the country....and probably of each other' (2004a, 80). These foreboding words mark the penultimate sentence of the essay, a statement of finality against which very few contrasting thoughts exist on tribe and mosque as political resources for a positive future.

The fatalism embedded in McGeough's argument is illogical, principally because it works against the central thesis of the essay, which is to criticise the neoconservative policy of bypassing the sheikhs. Billingsley summarises the US foreign policy goal in the Middle East as 'wholesale political reform in the region based on the imposition of a liberal democracy - the one true source of progress' (2004a, 23). McGeough powerfully testifies just how ill-conceived such an aspiration has proved to be. Yet at this point confusion arises: however foolish the original US plans for a liberal democratic Iraq might have been, Mission Impossible can be read as the defeat of liberal progress in Iraq because of the antidemocratic ontology of the tribe and mosque. In other words, McGeough knows whom ultimately to blame for the post-Saddam mess, and it's not the Americans. Given the incompatibility of worlds involved-the liberal democratic West and the primordial domain of the sheikhs — one could argue that the invaders and occupiers had little choice but to foist their 'liberal' will upon the Iraqi people. Following the fatalistic logic of McGeough’s argument, the neoconservative strategy of violent occupation thus becomes strangely vindicated.

\section{Framing the analysis}

There is, of course, nothing wrong per se with bleak or despairing analysis. Some of the defining narratives of our time depend upon it. It would be ludicrous, for instance, to condemn Albert Camus’ The Plague for its bleak texture-how else does one allegorise the German occupation of France but through a story of unforgiving pestilence? Yet Camus, whose subject is more sinister than McGeough's, wants also to tell us of human 
capability in the face of life disasters ['Ah, I understand sir. You're like me, you're a fatalist.' Tarrou: 'I had said nothing of the kind, and what's more, am not a fatalist. I told him so....' (Camus 1948, 26)] McGeough, by contrast, seems fatalistically compelled toward a tragic ending. The phrase 'the future of Iraq' in the subtitle of Mission Impossible is thus rhetorical-there is none, or at least none worth feeling hopeful about.

Is McGeough correct in his fatalistic analysis that the bedrock structures of Iraqi society are anti-democratic? I shall limit the consideration of this question to the relation between democracy and the deep cultural resource of religion. This is, of course, a large task that demands stringent control within the limited space of the present article. The two dominant Islamic traditions in Iraq, making up eighty per cent of the population, are the Shi'ite and Sunni. According to McGeough, while 'the tribal structure appears to be stronger than religion in the lives of Iraqi Sunnis, the reverse is the case for the Shi'ites for them the mosque is the dominant influence' (2004a, 34). Whilst not disregarding the importance of the tribes, in keeping with McGeough's framework I shall focus on the importance of mosque over tribe and offer an introductory analysis about the majority Shi'ite tradition in the region (Iran and Iraq) against the claim that it cannot be utilised as a resource for democracy.

Before analysing the Shi'ites in relation to democracy, however, it is worth exploring the question of democracy in relation to religion more broadly. The rationale for this approach, as shall be argued below, is that McGeough's fatalistic posture toward the Shi'ites in Mission Impossible stems from an a priori assumption about religion within the author's own secular framework. As such, it is with a critique of this assumption in McGeough's work and beyond that the present article is primarily concerned.

\section{Worlds apart? Reframing democracies in a religio-secular world}

In a recent article titled Worlds Apart, McGeough analysed the November riots in France by members of Muslim Middle Eastern and North African French communities thus: 'It is too simplistic to say it's all about religion and it's too dangerous to lump it in with the global jihad.' (2005) The essential problem behind the rioting is instead identified as a 
'freedom or democracy deficit'. Describing the Arab world as 'a corner of hell where the privation of mind, body and soul leaves many youngsters in the homelands ripe of the jihadist picking', for McGeough it is also an 'irony' that resistance to inequality and injustice in such a world comes from Islamic activists for whom 'religion is a protective bubble from which to challenge the status quo’.

It is noteworthy that in neither the analysis of the French context nor in the totalised sum of the Arab World is religion as religion given any political agency: explanations for Muslim discontent in France are purely materialist and structural; the prominence of Muslim activism on the moonscape of the Arab World is because there is no alternative. These perspectives are instructive in our attempt to identify McGeough's assumptions toward religious actors in relation to democracy in Iraq. Whilst not discounting the truths contained in Worlds Apart, there is no 'middle' place for Islamic actors between the poles of anonymity and extremism. Yet so often it is in the middle political space, described by Martin Krygier as neither hot nor cold but 'lukewarm' $(1997,57)$, where the notions of pluralism, civility, freedom and democracy are conceived.

For McGeough, and indeed many others before him, the middle space is by necessity a secular space. Religion does have its place within a secular framework, but according to prominent secular theorist Steve Bruce, only when religious interest groups 'accept the privatization of their distinctive religious beliefs and move on to secular ground' (2002, 21) allowing democracy to be facilitated by a 'neutral state' (Bruce, 2002 16).

Accordingly, secularization can be understood as the decline or containment of religion, both in society and in the minds of individuals, such that religious ideas and traditions no longer fundamentally shape the governance of a people (Bruce 2002, 1-45).

But is democracy solely a derivative of the secular? For McGeough the answer is 'yes' and this influences his negative reading of the Shi'ites as anti-democratic actors in a desperate Iraq. One of the foundational assumptions behind Mission Impossible, what might be called a secularist assumption, is that democratic norms cannot, in any credible sense, function within ethno-religiously defined structures of power (e.g. 2004a, 79). For 
instance, McGeough agrees with conservative analyst Patrick Basham’s lament that the current Iraqi middle class is unable to deliver 'democratisation', by which he means 'political debate in a secular, liberal fashion' (2004a, 79). Iraq is instead a domain where religious actors thrive in an 'ethno-religious cauldron' (2004a, 34) of 'prayers and death' (2004a, 31), and where those exercising power from the mosque have no intention to do business in the meeting tents of democracy.

What results from this approach is a denial of democratic alternatives to the one conceived by the secular liberal western tradition. For the author it seems near-impossible that such alternatives could ever evolve out of the primordial swamp of the mosque or the tribes: 'any attempt to foist bottom-up principles of rights and democracy onto societies that are so top-down driven will require a decades-long commitment.... Or more likely, it will simply fail.’ (2004a, 77) In what is from many angles a highly contestable assertion, McGeough writes 'In truth, except Israel, democracy does not exist in the Middle East, and this despite the sorrow of so much Western intervention in the region over the years.' (2004a, 77) As if to warn against manipulating the cultural DNA of the Middle East for the designer interests of the West, Mission Impossible thus reads as an extended 'I told you so', a secularist condemnation of primordial power and those who try to coopt it for modern causes.

\section{Exploring democracy in a religio-secular space}

A contrasting response to questions about whether democracy is secular is to hold that whilst democracy can be secular in form, it need not always be so. Numerous scholars in the sociology of religion and international relations argue that there exists an observable desecularization of world politics (e.g. Berger 2004; Thomas 2005; Westerlund 1996). If this is true, non-secular structures of power demand consideration as constituent elements in the architecture of democracy.

The Nobel laureate Amartya Sen has recently argued that democracy isn’t a 'western invention’ but is better understood as having ‘global roots' (Sen 2003). Sen argues (after Rawls) for 'a broader view of democracy in terms of public reasoning' $(2003,29)$. The 
inference drawn is that democracy 'has demands that transcend the ballot box' $(2003,29)$ and is better predicated upon the notions of 'tolerance and openness of public discussion' (2003, 31). As such, and in contrast to Rawls' ‘thin' notion of justice, this 'thicker' notion of democracy can be sourced in the history of cultures the world over.

The championing of pluralism, diversity, and basic liberties can be found in the history of many societies. The long tradition of encouraging and protecting public debates on political, social, and cultural matters in, say, India, China, Japan, Korea, Iran, Turkey, the Arab world, and many parts of Africa, demand much fuller recognition in the history of democratic ideas. (Sen 2003, 29-30)

It follows that a practical implementation of Sen's conception of democracy would require the (re)inclusion of religious traditions in the building of democratic institutions, and a belief that these traditions can make a fundamental contribution to pluralism (Thomas 2000). Part of this process involves reframing the political space into what Marty usefully calls the 'religio-secular world’ (2003) of international affairs. Marty’s attempt to find 'a new model for describing the world that we actually inhabit' (2003, 42), like Sen's call to reconceive democracy, acts as a salient criticism:

The old debates revolve around binary categories: societies were either secular or religious; worldly or other-worldly; materialist or spiritual; favoring immanence or transcendence, etc...[but] most people blur, mesh, meld, and muddle together elements of both the secular and the religious, the worldly and the other-worldly. (Marty 2003, 42)

We can employ this argument to credibly suggest that Mission Impossible is written within a binary framework where the reader is confronted with a war of the worlds - the domain of the sheikhs described as 'another world, a parallel universe' (2004a, 4) against that of the liberal democratic West. But is the West as 'secular' as Bruce and others suggest? Might, in accordance with Marty’s more integrated framework, some 'western' as well as ‘eastern' actors be better understood as religio-secular in outlook?

One need not be a secularist in order to be secular or liberal. In Why I Am Not A Secularist Connolly argues that 'secularism and liberalism are connected, though neither is entirely reducible to the other' $(1999,10)$. Connolly then suggests that 'secularism needs refashioning, not elimination' $(1999,19)$, and - in what could function as a salient definition of a post-secular politics - argues that this refashioning requires a 'reflective engagement...among a variety of religions and irreligions to support a more vibrant 
public pluralism' $(1999,6)$. For Connolly, the secular can be more 'engaged’ with a ‘deep pluralism’ (see 1999, 137-187) than the secularist might suggest.

If one need not be a secularist in order to be secular, neither does one need to be secular in order to be western. The political theorist Elshtain argues against what she perceives to be the 'liberal monism' of American politics thus:

\footnotetext{
One enters political life as a citizen. But if one also has religious convictions, these convictions naturally will inform my judgements as a citizen. My religious views help to determine who I am, how I think, and what I care about. This is as it should be. In America it makes no sense to ask people to bracket what they care about most deeply when they debate issues that are properly political. (Elshtain 2003, 79)
}

If this beyond-secular perspective can be argued in an American context, how much more so from cultural contexts fundamentally shaped by religious traditions as Iraq? Such a thought invites us to reframe what democracy is - what the constituent elements of it are, and from where these elements might be drawn.

\section{Religion America}

I have thus argued (after Sen) that democracy is not exceptional to the 'West', and suggested (after Connolly and Elshtain) that religion is not exceptional to the politics of the 'East'. Relevant to the present discussion, one of the best examples of the complicated interaction between culture and religion in the 'West' is found in the United States itself. McGeough pits the secular West in a zero-sum fashion against the mosque. As a US-initiated and US-led occupation, it follows that the US is acting with secular intent. In some ways this is true. Whilst George W. Bush might at times present as a soldier for Christ, pivotal neocon strategists like Wolfowitz and Pearl, or administration heavyweights like Cheney and Rumsfeld, have no overt religious profile. Yet does this mean there is no religious agenda in a broader political sense?

The effect of religion upon US policy cannot be measured by religious affiliation alone, but extends to understanding the scope and purpose of political power by those who seek to wield it. In what some understand to be a unipolar world of American hegemony, the US has become, as Mandelbaum puts it, the 'hyperpower' of world politics (2002, 61). In 
celebrating this hyperpower America has experienced a religious conversion-to itself. 'The US is no longer just a nation', writes George Monbiot, 'it is now a religion.... The United States no longer needs to call upon God; it is God, and those who go abroad to spread the light do so in the name of a celestial domain. The presidency is turning into a priesthood.' (2003) Monbiot's thesis is not original, but it does contextualize a widelyheld view that at the foundations of US identity lie fundamentally religious concepts. This is, in many ways, not exceptional to the US, but conforms to what Anthony D. Smith calls 'the sacred dimension of nationalism' (Smith, 2000). What does seem unprecedented is the depth of missionary zeal produced when US nationalism is imbibed with hegemonic confidence.

McGeough deftly conveys the religious nature of the US mission in Iraq when he describes it as ‘dreamy’ (2004a, 7). This incisive term offers insight into American motivations in Iraq. In a speech to the American Enterprise Institute on the day before the shock and awe of US military omnipotence was unleashed, President Bush 'dreamily' acknowledged the immanence of the campaign as if it were a sovereign dispensation. Critically observed, this was a performance of soft revivalism, the preacher telling it like it is, not so much defending the faith as submitting to its presence-the manifest destiny of Religion America. Once hostilities had commenced, Bush lavished the US campaign with the ancient words of Isaiah 61: 'to the captives come out, and to those in darkness be free' (Monbiot 2003). In other words, the US is the harbinger of peace with justice, led by a President who presides over a binary world of good and evil (Singer 2004).

The example of Religion America above is usefully negative. This is not because the religious energies within a nation have no positive potential, but because it neutralises any exceptionalist charge that Shi'ite error or excess in the Middle East is solely due to its religious moorings. Can the religious energies of a nation also be utilized in a constructive process of participatory democratisation? The religio-secular frame offers a useful heuristic tool for challenging notions of the mosque as always undemocratic and exploring post-secular democratic possibilities. 


\section{Toward a post-secular conception of Iraqi democracy}

In a strong critique of Mission Impossible, Anthony Bubalo argues 'it is time we changed the paradigm for talking about democracy in the Middle East’ (2004a, 134) and, echoing Sen, states that 'today democracy is not for the West to export or impose’ (Bubalo 2004a, 134). Similarly, Stewart has appealed to the need for a new lexicon on Iraq: 'The gap between the way foreigners talk about Iraq and the reality is monstrous. Our political vocabulary__rogue states”, ”nation-building intervention”, ”WMD”, “neo-imperialism”, “terrorism”-is useless.' (Stewart 2005, 9) Stewart's main argument, contrasting the fatalistic logic of Mission Impossible, is that most if not all actors in Iraq 'have almost no idea what Iraq is like or is going to be like' $(2005,9)$. Stewart's view serves to highlight how radically premature McGeough's thesis of impossibility is, and it also encourages the exploration of alternatives to such a view.

\section{Tribe and mosque as sources of pluralism}

Bubalo sums McGeough’s argument as ‘culturalist' $(2004,136)$ and rightly indicts Mission Impossible for depending on 'caricature'. Caricature is marked by fixing and exaggerating certain qualities of a subject, and in so doing, ignoring the more complex and dynamic nature of real-life entities. By using immovable metaphors such as 'bedrock', McGeough seems neglectful of the dynamic quality of the tribe and the mosque to adapt and contribute to an indigenous democratic polity. Yet on numerous occasions McGeough details aspects of these 'bedrock' structures that, if reframed, could be seen as possible sources for pluralism and diversity.

For instance, with appeal to the tribal leadership of the sheikhs in Iraq, Bubalo argues that traditional structures of power are malleable and open to democratic process:

Isn't it possible to want strong leaders and at the same time to appreciate the ability to choose the strong leader you want?... The fact that sons and brothers are often passed over when it comes time to choose a new tribal leader underlines the extent to which fitness to rule and consensus are also important parts of [tribal] ethos. (Bubalo, 2004 136)

Moreover, many of the tribes are religiously mixed, having members of the majority Shi'ite and minority Sunni communities within them. This diverse membership could form the foundation for inter-Islamic discourse on issues of security-the only possible 
role McGeough can see for the tribes (2004a, 61-70)—conflict mediation and governance. Piggott has recently suggested that throughout the Middle East and North Africa the politics of the tribe will always prevail over religious affiliation $(2005,19)$. But this need not always be so, and the prospect of transforming contexts of internecine violence might depend on the agency of pluralism within the religious traditions and by a more explicit utilisation of religious resources such as sacred texts to deeply indigenise a post-secular democratic culture (Rees, 2004).

\section{Reframing Shi'ite politics}

A consideration of secularism above leads us to one of the defining tensions within Mission Impossible. Whilst the author forcefully describes what is so wrong with the US strategy of 'crafting a secular administration that would be dominated by the hand-picked exiles Washington had airlifted into the country’ (McGeough 2004a, 7), working against his own thesis, McGeough's secularism reinforces US concerns upon which this very strategy was based: 'They feared that if liberated Iraqis were left to their own devices, the mullahs would demand an Iranian-style theocracy....' (2004a, 7) A necessary focus of McGeough's thinking about Iraq is the pivotal place of the majority Shi'ite community. The Sheikh of Sheikhs in Iraq is the Iranian-born Grand Ayatollah Ali al-Sistani. It is no exaggeration to suggest that the spectre of al-Sistani haunts Mission Impossible and its author. Indeed, such is McGeough's fascination with the Grand Ayatollah, one could be forgiven for thinking the term 'enigmatic’ was part of Sistani's official title. McGeough interprets al-Sistani with a nervous awe: awe at the pre-secular origins to his authority, and nerves at the autonomy that this provides. He writes,

\footnotetext{
In the year since Bush landed his invasion force in Iraq, Najaf has reasserted itself as the spiritual heart of the country. The back-alley office of the Grand Ayatollah al-Sistani has become a serious rival to Baghdad as a seat of political power. To this day the Grand Ayatollah remains an enigma. He has no political party and no army. He rarely speaks his mind and he hardly ever ventures from the ascetic home where he receives few guests - and certainly not Bush's man in Iraq, Paul Bremmer. (2004a, 37)
}

When does al-Sistani's autonomy become subversion? What is the risk of including alSistani in the circle of power, as his call for popular elections and criticisms of the interim constitution seem to indicate he expects? One word sums up McGeough’s concern: Iran. 
Even if al-Sistani compromises and accepts a US-sponsored framework for the future political development of Iraq...there are grave fears among secular Shiites and non-Shiite Iraqis that an alSistani dominated regime might quickly evolve into something very different, perhaps something very theocratic, maybe something very Iranian. (2004a, 35)

McGeough's perspective is problematic. The sheer otherness of al-Sistani-described by McGeough as 'a robed and bearded near-saint, a formidable opponent who says very little but means what he says' (2004a, 34)—and of the Shi'ite tradition that he represents, produces in Mission Impossible a sloppy and prejudicial reading of Shi' ite politics that effectively shuts-out any place for the Shia in a democratic Iraq. Whilst acknowledging the political and theological diversity that exists in any religious community, given the Shi'ites comprise sixty per cent of the Iraqi population one can immediately see the impracticality of McGeough view.

Of course, McGeough's caricature of al-Sistani confronts the reader with another 'enigmatic' Ayatollah, the leader of the Iranian revolution in 1978-79, Ruhollah Khomeini. Iran is often held up as proof that Islamic religious politics are retrograde, a point re-emphasised by the recent elections which were far more fixed than free. 'Theocracy' has thus become an epithet for all that is wrong with political religion, particularly of an Islamic kind. When the Iranian revolution occurred its leaders were portrayed as ghosts from a past age, backwards in time and outlook, fundamentalists with little to offer the modern world. This was, and remains, the view of many opponents of Iran, none more so than the US. Iran has been the object of an unrelenting campaign by the US to paint it as an evil other, an aberration in world politics, whilst trumpeting the trustworthiness of 'moderate Arab states like Saudi Arabia' (Rice 2000, 60).

This last statement was made in 2000 by Condeleeza Rice, now US Secretary of State. Rice holds the concept of a 'moderate' Saudi Arabia against a fixed and negative portrayal of Iran, describing the latter as trading in 'fundamentalist Islam' (Rice 2000, 60). One can quickly see the illogic of such a view. Saudi Arabia is at best autocratic and, it should not go unnoticed, most of the 9/11 hijackers were middle-class Saudi nationals. More poignantly, one need only examine the Wahhabist tradition of the Saudis to place Shi'ite nationalism in comparative perspective. As the anthropologist Geertz puts it, 
Wahhabism...is the name generally given to the radically puritanical version of Islam dominant to the point of absolutism in present-day Saudi Arabia - the sort that stones adulterers, decapitates apostates, forbids female-car driving, and, apparently, breeds such people as Osama bin Laden.' (Geertz 2003, 37)

By contrast, the closer one examines the politics of Iran the more one sees not the fixed fundamentalism of religious political control, but rather, a very dynamic process of political evolution within the interpretive tradition of Shi'ite Islam (Armstrong 2000).

The fixed nature of the term 'theocracy' implies rigidity and a disengagement from contemporary culture. And, if the erroneous judgements and oppressive eccentricity of the Iranian regime were our only focus, there is plenty of rigidity to be found. However the Iranian revolution can also be reframed as 'a multi-faceted revolutionary movement led by a religious opposition that appealed to widespread anti-Western and anti-tyrannical feelings' (Keddie 2003, 24). Moreover, it was fundamentally shaped by the international climate of the Cold War period and was 'neither east nor west' in essence (Keddie and Gasiorowski, 1990). As with all post-secular political processes, which in this case is directly linked to the many post-colonial changes occurring in world politics in second half of the twentieth century, Shi'ite religion in Iran is highly complex. Complex, but not enigmatic.

\section{Diversity and evolution in Shi'ite politics}

I draw on two aspects of the Shi'ite revolution in Iran that challenge McGeough's caricature of Shi' ite politics in Iraq. The first is a de-linkage: Shi'ite politics is diverse and cannot be neatly exported from Tehran to Baghdad. In his seminal history of the Arab peoples, Hourani argues that 'the revolution could be explained in terms of factors specific to Iran’ (1991, 457). Hourani continues, ‘[In Iran] certain powerful classes were particularly responsive to appeals expressed in religious language, and there was a religious leadership which was able to act as a rallying point for all movements of opposition', whereas in Iraq 'where Shi'is formed a majority, their men of learning did not have the same intimate connection with the urban masses or the same influence on the government as in Iran.' (Hourani 1991, 457-458) In other words, theories of a pan-Shi' ite ‘theocratic’ polity must first deal with the Iranian-Iraqi diversities and not simply conflate 
leaders and traditions across cultural, linguistic and historic divides simply because they share the same religious tradition. Notably, this generic regard for the Shi'ites parallels the neoconservative assumption that context and culture matter little in relation to democracy. It is therefore erroneous to invest the Shi'ites with a 'civilisational' unity that ignores the many clashes and/or differences that exist within the tradition. At times McGeough acknowledges this diversity, but only to develop the argument about violence and vested interest in Iraqi society. Headlining the fear that 'the Shi'ites are coming!' might make good copy for secularists in Iraq and elsewhere, but it is in defiance of the cultural complexity that is the very stuff of politics, whether 'eastern or 'western'.

The second aspect is a linkage between Iranian and Iraqi Shi'ites. Against the thesis that the Iranian Shi'ites were ghosts from a past age, it is important to understand that Khomeini was not a traditionalist in Shi'ite religion but an innovator. His interpretive theory of Velayat-i-Faqih (Mandate of the Islamic Jurist) controversially called for Shi'ite involvement in government and was opposed by conservative Shi'ites. This was also different from the pan-Islamic polity implicit in the concept of umma where the faith community is not organised within the fences of any state. 'In an Islamic context,' writes religious scholar Armstrong, 'Khomeini’s message was modern’ (2000, 2). Thus, as an innovative interpretive project, Iranian politics reflects an evolving process of post-secular political formation, first from secular to religio-secular autocracy, and now from religiosecular autocracy to religio-secular democracy.

This evolutionary process is reflected in the wider Islamic world (Hofmann 2004; Tamimi 2001; Abootalebi 1999). Scholars such as Frederic Volpi are also beginning to reframe Islamism as a potential form of pseudo-democracy alongside republican and liberal models (2004). Whatever obstacles one might acknowledge in Islamism's march toward democracy, it is imperative that such an option be given central consideration. Volpi invokes Olivier Roy's view that 'the issue of the state in the Middle East cannot be properly addressed without reference to the loci of personal allegiances created by solidarity groups (asabiyya), networks and communities (particularly religious ones)' (Volpi 2004, 1065). Such logic seems strengthened by McGeough’s own observation that 
'[i]n the vacuum left by the toppling of Saddam, the mosque was one of the few remaining threads of the social fabric that survived’ (McGeough 2004a).

Volpi's term 'pseudo-democracy' is somewhat confusing given that he favorably compares Islamic with liberal and republican democratic models. It is perhaps more useful to try and distinguish, as Feldman attempts to do (2003), between Islamist and Islamic democracy. This distinction is useful when analyzing Shi'ite politics in Iran.

Iran and the possibility of post-secular democracy in Iraq

That the Iranian evolution has stalled, and may possibly grind to a halt under new President Ahmedinejad, says very little about Shi'ite politics per se and more about the ability of autocrats to hang on to power. Such intransigence is not unique to Islamism, but can also be seen in the behaviour of republican and liberal democratic elites (Volpi 2004, 1070-1074). It also suggests that the movement toward liberalisation by progressive Shi'ites under former President Khatami was not supported by a commensurate level of Presidential power over the military and security forces (Abdo and Lyons 2003, 121122).

In a simple, if not simplistic, alternative analysis McGeough holds that in Iraq the 'Iranian' alternative - meaning the Shi'ite alternative-is little more than the imposition of 'theocracy’. By this epithet, McGeough conflates theocracy with autocracy, and turns al-Sistani and Khomeini into a single composite medieval figure not to be trusted with the future of Iraq. In a telling conversation with McGeough, Sheikh Mohammed Hussien alKinana dismisses McGeough’s suggestion that many in the West saw Khomeini as an extremist. 'That is only because people in the West don't understand Khomeini.' (2004, 45) One need not be an apologist for Khomeini to see the truth of this statement. Understanding the possibility of a Shi'ite-led post-secular democracy in Iraq may require a reframing that goes back to Tehran.

It is readily acknowledged that al-Sistani is no fan of aspects of the Iranian experiment. There are two ways one could interpret what ensues from this view. Either al-Sistani no 
longer believes in Shi'ite governance, a view that cannot be reconciled with his public statements since the occupation and his patronage of the Shi'ite majority in the new elected parliament. Alternatively, al-Sistani is also an innovator and is consciously trying to develop the Shi'ite political alternative further. If Shi'ite politics can be reframed as evolving from autocracy to democracy, and if al-Sistani can influence Iraqi democracy and government in the same way he brokered a civil resolution to the siege of Najaf in August 2004, then history might well record how Iraq built the post-secular democracy that the Iranians never got.

Numbers will of course help this process. The Shia comprise only 60 per cent of Iraqis, unlike 90 per cent in Iran, and will thus be forced into a national unity strategy with both Kurds and Sunnis. Beyond the process of coalition building, the acid tests of gender and minority rights must also be used to scrutinize the bona fides of any new government. These are the substantive issues of implementation, and it is readily acknowledged that there is long way to go in the process of democratic formation. There is nothing exceptionally 'post-secular' about any of this, yet these are the very possibilities that McGeough and others have suggested are impossible in Iraq because of the Iran-Shi'ite connection.

Before any policy development can begin in earnest in Iraq, what is ultimately required is a change in the assumptions about Islam as a resource for democratisation. Beyond Iran and Iraq, scholars such as Keane argue that Islamism plays a vital role in bringing new visions of civil society into being. For instance, as a counter to the 'compulsory secularism' of the military autocracy in Turkey, Keane highlights the role of 'Muslim actors intent on developing and redefining civil society—pushing toward a post-secular civil society, structured by new codes of ethics and aesthetics and held together and institutionally protected by new post-secularist government policies in such fields as law, education, municipal administration, banking and foreign affairs’ (Keane 1998, 28). For Keane, the concept of 'global civil society' marks an evolution toward a 'new cosmology' (2003, 1-39) that employs 'religious civilisations' as a catalyst because they have 'developed world-views and world-girdling institutions that feed the streams of 
social life that are today global' (Keane 2003, 40). In a powerful recasting of

'civilisational' rhetoric in the security discourses of scholars such as Huntington (1996),

Islamic civilisation plays a central role in the search for post-secular civility and democratic participation (Keane 2003, 40-43).

Specific to Iraq, Noah Feldman, a principal consultant in the design of the interim constitution of Iraq, argues for the prominence and necessity of Islamic traditions in a post-Saddam democratic era. He writes,

Post-Saddam Iraq would pose an ideal opportunity for the world to show its openness to the possibility of Islamic democracy, by embracing any political parties or organisations that promise to work within the structures of democratic constitutional government. That would mean that ideas associated with Islam would figure in an Iraqi constitutional convention, and that Islamic democrats would be able to participate in a subsequent government.... A new government would have little chance of being legitimate if the Iraqi people were denied the opportunity to rely on the ideals and values of Islam to create it. (Feldman 2003, 180)

Not only are we presented with Islam as a primary political resource, we are confronted with the creative imperative to include Islamic concepts (Hanafi 2002) in a democratic context that will not have it otherwise, such is the nature of democracy.

\section{Beyond Orientalism}

Bubalo describes the argument presented in Mission Impossible as one of 'loving and loathing' the Arabs (2004, 132). This is an understandable but overstated critique, and McGeough is justifiably defensive to the charge (McGeough 2004b, 140-141). I believe the entanglement of incisive commentary, astute description, yet also fatalism and blinkered secularist assumption that exists in Mission Impossible indicates a more complicated dynamic that is better described as Orientalist. Edward Said, perhaps the most authoritative voice on the subject, described Orientalism as 'the corporate institution for dealing with the Orient-dealing with it by making sense about it, authorising views of it, describing it, by teaching it, settling it, ruling over it: in short, Orientalism is a Western style for dominating, restructuring and having authority over the Orient' (Said 1978, 1995, 3). In this essay I have criticized McGeough’s view that traditional Iraqi structures of tribe and mosque exist in a parallel universe to the so-called liberal democratic west. Whatever the author's explicit intention, such an approach effectively 
contains and controls Iraqi structures of power, negating their utility as political resources in the contemporary world. This is not done as an overt act of hostility, but rather, it is achieved through a critique of imperial power via 'Iraqi voices'. Thus Mission Impossible at once limits traditional Iraqi power, advocates for Iraqi freedom, and dismisses Iraqi capacity to build a positive future.

Said also asserted what many now take for granted, that 'ideas, cultures and histories cannot seriously be understood or studied without their... configurations of power also being studied' (1978, 1995, 5). This McGeough does by a commendably intimate investigation into the milieu of the sheikhs. However, Said also argues that 'because of Orientalism the Orient was not (and is not) a free subject of thought or action' (1978, 1995, 3). Applied to the current discussion, Keane observes that many Islamists 'insist that secularism ...effectively functions as an Orientalist ideology that protects despotic states bent on stifling the growth of civil societies within the Muslim world' $(1998,27-$ 28). Such an unfreedom is assured in Mission Impossible due, as the title forecasts, to the underlying fatalism toward the indigenous structures of Iraqi culture, and thus to McGeough’s Orientalist posture.

That the views of an experienced western foreign correspondent can (still) be thoroughly deconstructed in the first five pages of a now classic text of cultural theory is more than a little discouraging. Reporting political change in the religio-secular space demands a new way of seeing and being in the emerging political forms of a religio-secular world. Whatever problems the authority structure of the mosque may have in its transition toward democracy, it seems absurd to suggest that it offers less preferable resources for Iraqi democracy than the just-as-traditional authoritarian violence that the 'west' has so often sponsored in the Middle East. Engagement with significant non-secular actors such as the Shi'ites to help concieve an Iraqi democracy is, by any measure, a necessary and worthwhile enterprise. Sen argues that 'the value of public reasoning applies to reasoning about democracy itself.' (2003, 34). As I have reasoned above, reframing the assumptions that underlie the descriptions in Paul McGeough’s Mission Impossible might help conceive a better democratic framework that includes the sheikhs, the 'west', and post- 
secular democratic possibility.

\section{Reference List}

Abdo, G. and Lyons, J. 2003, Answering to God: Faith and Freedom in Twenty-First Century Iran, Henry Holt Co, New York.

Abootalebi, A.R. 1999, Islam, Islamists and democracy', Middle East Review of International Affairs 3.1, 14-24.

Armstrong, K. 2000, 'In Defense of Khomeini', AFR Review, 20 October, 1-11. Berger, P.L. 1999, 'The Desecularization of the world: a global overview' in: The

Desecularization of the World, Berger, P.L. (ed), 1999, Eerdmans, Michigan,, 1-18. Billingsley, A. 2004, 'The native scene' The Diplomat, Aug-Sept, 23-25.

Bruce, S. 2002, God is Dead. Secularization in the West, Blackwell, Oxford.

Bubalo, A. 2004, 'Mission Impossible: correspondence', Quarterly Essay, 15, 132-136.

Connolly, W.E. 1999, Why I Am Not a Secularist, University of Minnesota Press, Minneapolis.

Elshtain, J.B. 2003, ‘Against Liberal Monism’, Daedalus, Summer, 78-79.

Feldman, N. 2003, After Jihad. America and the Struggle for Islamic Democracy, Farrar, Strauss \& Giroux, New York.

Gertz, C. 2003, 'Which way to Mecca? part II', The New York Review of Books, July 3, 36-39.

Hanafi, H. 2002, 'Alternative conceptions of civil society: a reflective Islamic approach'. in: Alternative Conceptions to Civil Society, Chambers, S. and Kymlicka, W. (eds.), Princeton University Press, Princeton, 171-189.

Hofmann, S.R. 2004, 'Islam and democracy. Micro-level indications of compatibility', Comparative Political Studies 37.6, 652-676.

Hourani, A. 1991, A History of the Arab Peoples, Harvard University Press, Cambridge, Mass.

Huntington, S.P. 1996, The Clash of Civilizations and the Remaking of World Order, Simon \& Schuster, New York.

Keane, J. 1998, Civil Society: Old Images, New Visions Blackwell, Oxford. 2003, Global Civil Society? Cambridge University Press, Cambridge.

Keddie, N. and Gasiorowski, M.J. 1990, Neither East Nor West. Iran, the Soviet Union and the United States, Yale University Press, New Haven and London.

Keddie, N.R. 1995, Iran and the Muslim World: Resistance and Revolution, MacMillan, London. 2003, 'Secularism and its discontents', Daedalus, Summer, 14-30.

Krygier, M. 1997, Between Fear and Hope. Hybrid Thoughts on Public Values, ABC Books, Sydney.

Mandelbaum, M. 2002, 'The inadequacy of American power', Foreign Affairs, September/October, 61-73.

Marty, M.E. 2003, 'Our religio-secular world', Daedalus, Summer, 42-48.

McGeough, P. 2004a, 'Mission impossible: the sheikhs, the US and the future of Iraq', Quarterly Essay, 14.

2004b, 'Mission impossible: correspondence', Quarterly Essay,15, 137-148. 
Monbiot, G. 2003, ‘America is a religion’, The Guardian, 29 July.

Philpott, D. 2002, 'The Challenge of September 11 to secularism in international relations', World Politics, 55, October, 66-95.

Piggott, L. 2005, 'Tribalism in the Arab MENA region', Policy, 21.1, 15-20.

Rees, J.A. 2004, “"Really existing scriptures”: on the use of sacred text in international affairs', The Brandywine Review of Faith and International Affairs, 1.2, 17-26.

Rice, C. 2000, 'Promoting the national interest', Foreign Affairs, January/February, 4562.

Robbins, J.W. 2004, 'A Post-national theology of empire', Journal of Cultural and Religious Theory, 5.3, 1-6.

Roy, O. 1997, 'Islamists in power', in: The Islamism debate, Kramer, M. (ed), The Moshe Dayan Center for Middle Eastern and African Studies: Tel Aviv University, 69-85.

Said, E. 1995 (1978), Orientalism, Penguin, London.

Sen, A. 2003, 'Democracy and its global roots', The New Republic, 6 October, 28-35.

Singer, P. 2004, The President of Good and Evil, Plume Books, New Jersey.

Smith, A.D. 2000, 'The "sacred” dimension of nationalism', Millennium: Journal of International Studies, 29.3, 791-814.

Stewart, R. 2005, 'Degrees of not knowing', London Review of Books, 31 March, 9-11.

Tamimi, A.S. 2001, Rachid Ghannouchi: A Democrat Within Islamism, Oxford University Press, Oxford.

Thomas, S. 2000, 'Taking religious and cultural pluralism seriously: the global resurgence of religion and the transformation of international society', Millennium: Journal of International Studies, 29.3, 815-841.

Thomas, S. 2005, The Global Resurgence of Religion and the Transformation of International Relations. The Struggle for the Soul of the Twenty-First Century, Palgrave MacMillan, New York.

Volpi, F. 2004, 'Pseudo-Democracy in the Muslim world', Third World Quarterly, 25.6, 1061-1078.

Westerlund, D. 1996, Questioning the Secular State: The World-Wide Resurgence of Religion in Politics, Hurst \& Company, London. 